\title{
第37回内科学の展望
}

\section{2. メタボリックシンドロームの現状と課題一疫学を含めて}

島本 和明

Key words：インスリン抵抗性, 国際糖尿病連盟（IDF）, NCEP, 端野・壮瞥町研究

はじめに

LDLコレステロールや喫煙とは独立した動脈 硬化のハイリスク状態としてメタボリックシン ドロームが注目されている，肥満・高血圧・糖 尿病・脂質異常症（高中性脂肪血症と低HDL コレステロール血症）は，それぞれ独立した動 脈硬化性心血管疾患の危険因子であると同時に, 互いに腹部肥満やインスリン抵抗性という共通 の背景因子を持ち, 相乗的に動脈硬化の危険因 子として関わる.

1999 年WHOより診断基準を明確にした上で, インスリン抵抗性あるいはそれを反映する糖代 謝異常を必須項目とした立場よりメタボリック シンドローム1) という呼称が提唱された。 2001 年のNational Cholesterol Education Program （NCEP）は，心血管疾患危険因子の集積状態を WHOのそれとは別の診断基準でメタボリックシ ンドローム ${ }^{2)}$ として提案している. 最近は肥満, 特に腹部肥満の本症候群における役割が重視さ れ，基準にも反映されつつある。 2005 年 4 月に International Diabetes Federation (IDF) より新 しい基準が検討され，腹部肥満を必須とする新 診断基準が示された ${ }^{3)}$. 本邦においては日本動脈 硬化学会, 高血圧学会, 糖尿病学会, 肥満学会,

しまもと かずあき：札幌医科大学第二内科
循環器学会, 腎臓学会, 血栓止血学会, 内科学 会の 8 学会で腹部肥満を必須とする本邦の診断 基準を検討し, 2005 年 4 月に公表に到っている ${ }^{4}$. このように国内外で多くのメタボリックシンド ロームに診断基準が提案されているが, 2009 年 9 月IDFより腹部肥満を必須としない新しい診 断基準5)が提唱され，新たな論議を呼んでいる.

本稿では, メタボリックシンドロームの現状 と課題について疫学成績も含めて紹介する.

\section{1. 病態と診断基準}

メタボリックシンドロームに代表される multiple risk factor症候群は, インスリン抵抗性を共 通の背景因子として他の危険因子が重積すると の考えであった. 1999 年に, それまでのインス リン抵抗性を背景とし, 冠危険因子が集積する multiple risk factor syndromeの病態に対して, $\mathrm{WHO}^{1)}$ がメタボリックシンドロームと呼ぶこと を提唱し，臨床診断基準を提示して以来 2009 年までに 8 つ異なるメタボリックシンドロー ムの診断基準が提案されている. そのうち, WHO (国際保健機構, 1999 年), EGIR (European Group of Insulin Resistance, 2001 年), AACE (American Association of Clinical Endocrinologist, 2003 年）は,インスリン抵抗性あるいはそれを表す 糖代謝異常を必須として，他の危険因子の集積 した病態としている。 又, NCEP-ATP III(2001 


\section{表 1． 国際糖尿病連盟の新しい診断基準}

1.この10年間で多くの診断基準が提唱されている が, 大きな課題は, 腹囲の測定値亡腹部肥満が必須 かどうか

2. 国際糖尿病連盟は, $N I H, A H A$, 世界心臓連盟, 国際動脈硬化学会, 国際肥満学会との合意の下に, 新しい基準を提唱

3. 腹囲測定による内臓肥満評価はスクリーニングと して有用である。基準值は各国, 地域のものを用 いる.

4. 腹囲測定による内臓肥満は, 診断基準で必須とし ない

5. 腹囲以外の項目の基準値は共通とする

年) ${ }^{2)}$, AHA/NHLBI (American Heart Association, 2005 年 $)^{6)}$ は 5 つの危険因子を同等に扱い, 3 つ以上の集積をメタボリックシンドロームとし ている。一方, IDF (国際糖尿病連盟 2005 年), 本邦の 8 学会の診断基準 $\left(2005\right.$ 年 $\left.{ }^{4}\right)$ では, いず れも腹部肥満を必須項目とし, 加えて他の危険 因子の集積としている. 本邦においては日本動 脈硬化学会, 高血圧学会, 糖尿病学会, 肥満学 会, 循環器学会, 腎臓学会, 血栓止血学会, 内 科学会の 8 学会で診断基準を検討し， 2005 年 4 月に公表に到っているが, IDF同様に腹囲による 腹部肥満を必須条件とし, 血圧高值, 血糖高值, 脂質異常 (高TG症, 低HDL-コレステロール血 症）の 3 つのうち 2 つ以上を基準としている. このように, メタボリックシンドロームの診断 基準は大きく 3 つのカテゴリーに分かれるが, 国際的にも必須基準の統一が望まれる中で, 2009 年 9 月に $\mathrm{IDF}^{5}$ が, NIH, AHA, 世界心臓連盟, 国際動脈硬化学会, 国際肥満学会と共に新しい 診断基準を提唱した．表 1 に示すように，これ まで異なっている診断基準を国際的に統一しょ うとするもので, 腹部肥満を必須とせず, 腹囲 基準は各国の基準をとるとしており，他の 4 つ の基準值は国際的に統一するとしている。 その ため，腹部肥満を必須とする診断基準は本邦の みとなり，今後国内においても診断基準につい て議論されることになると思われる. IDFでは表 2 に示すように, 腹囲については各国の診断基準 を用いて良いとしている。内臓肥満の基準值と
しての腹囲は，欧米ではBMIを中心に設定して いるため女性は男性より低值となっている。本 邦の基準值は日本肥満学会のガイドラインの值 を採用しているが, 腹部肥満を腹部でのCTにて 内臓脂肪面積を計測し，それによって男女のリ スク集積が有意に増加する值として内臓脂肪面 積 $100 \mathrm{~cm}^{2}$ を用いたものである. そして, $100 \mathrm{~cm}^{2}$ に相当する腹囲が男性 $85 \mathrm{~cm}$, 女性 $90 \mathrm{~cm}$ として いる．一方，ガイドライン制定時には，他には 報告は認められなかったが, その後Miyawaki) ら, $\mathrm{Hara}^{8)}$ ら, Eguchi ${ }^{9)} ら も$ 検討し, 腹部CT, 腹囲, 2 つ以上のリスクの集積を検討し, リスク集積に は男性で腹囲 85〜 86 cm以上, 女性では 77〜80 $\mathrm{cm}$ 以上がカットオフポイントであることを報告 している. 現在の本邦の状況では, 相対危険度 では男性は $85 \mathrm{~cm}$, 女性は $80 \mathrm{~cm}$ がカットオフ值 となる.一方, 介入ではハイリスクストラテジー をとることが多く,女性の $90 \mathrm{~cm}$ はそのような介 入を考慮した基準值とも言える.

新しいIDFの診断基準でも述べられているが, 本邦の診断基準值と, IDF，WHOアジアの基準 などのもう一つの大きな相異点は, HDL-コレス テロールの女性の基準值である。この点につい ても，今後本邦の基準を考える上で議論される ことになろう.

\section{2. 本邦におけるメタボリックシンドロー 厶の疫学}

\section{1）頻度}

本邦の診断基準によるメタボリックシンドロー ムの頻度については, 平成 16 年の国民健康・栄 養調査の成績より算出した厚労省の成績では, 加齢と共に男女共に頻度は増し，40 歳以上の男 性で $26 \%$ ，女性で $10 \%$ であった．平成 20 年の 成績も男性 $27 \%$ ，女性 $12 \%$ でほぼ同様である。 端野・壮瞥町研究の対象で, メタボリックシン ドロームに関する本邦の診断基準を用いて，端 野・壮瞥町研究の対象において疫学解析を施行 
表 2. Current Recommended Waist Circumference Thresholds for Abdominal Obesity by Organization

\begin{tabular}{|c|c|c|c|}
\hline \multirow{2}{*}{ Population } & \multirow{2}{*}{ Organization (Reference) } & \multicolumn{2}{|c|}{$\begin{array}{l}\text { Recommended Waist Circumference } \\
\text { Threshold for Abdominal Obesity }\end{array}$} \\
\hline & & Men & Women \\
\hline Europid & IDF (4) & $\geq 94 \mathrm{~cm}$ & $\geq 80 \mathrm{~cm}$ \\
\hline \multirow[t]{2}{*}{ Caucasian } & WHO (7) & $\begin{array}{l}\geq 94 \mathrm{~cm} \\
\text { (increased risk) }\end{array}$ & $\underset{\text { (increased risk) }}{\geq 80 \mathrm{~cm}}$ \\
\hline & & $\begin{array}{l}>102 \mathrm{~cm} \\
\text { (still higher risk) }\end{array}$ & $\begin{array}{l}\geq 88 \mathrm{~cm} \\
\text { (still higher risk) }\end{array}$ \\
\hline United States & AHA/NHLBI $($ ATP II $) *(5)$ & $\geq 102 \mathrm{~cm}$ & $\geq 88 \mathrm{~cm}$ \\
\hline Canada & Health Canada $(8,9)$ & $\geq 102 \mathrm{~cm}$ & $\geq 88 \mathrm{~cm}$ \\
\hline European & European Cardiovascular Societies (10) & $\geq 102 \mathrm{~cm}$ & $\geq 88 \mathrm{~cm}$ \\
\hline Asian (including Japanese) & IDF (4) & $\geq 90 \mathrm{~cm}$ & $\geq 80 \mathrm{~cm}$ \\
\hline Asian & WHO $\left(\begin{array}{lll}1 & 1\end{array}\right)$ & $\geq 90 \mathrm{~cm}$ & $\geq 80 \mathrm{~cm}$ \\
\hline Japanese & Japanese Obesity Society (12) & $\geq 85 \mathrm{~cm}$ & $\geq 90 \mathrm{~cm}$ \\
\hline China & Cooperative Task Force (13) & $\geq 85 \mathrm{~cm}$ & $\geq 80 \mathrm{~cm}$ \\
\hline Middle East, Mediterranean & IDF (4) & $\geq 94 \mathrm{~cm}$ & $\geq 80 \mathrm{~cm}$ \\
\hline Sub-Saharan African & IDF (4) & $\geq 94 \mathrm{~cm}$ & $\geq 80 \mathrm{~cm}$ \\
\hline $\begin{array}{l}\text { Ethnic Central and South } \\
\text { American }\end{array}$ & IDF (4) & $\geq 90 \mathrm{~cm}$ & $\geq 80 \mathrm{~cm}$ \\
\hline
\end{tabular}

*Recent AHA/NHLBI guidelines for metabolic syndrome recognize an increased risk for CVD and diabetes at waist-circumference thresholds of $\geq 94 \mathrm{~cm}$ in men and $\geq 80 \mathrm{~cm}$ in women and identify these as optional cut points for individuals or populations with increased insulin resistance.

表 3. 端野・壮瞥町研究対象者における我が国の新しい診断基準によるメタボリッ クシンドローム各危険因子の頻度（治療者除く/治療者含む）

\begin{tabular}{|c|c|c|c|}
\hline \multicolumn{2}{|c|}{ 男性 } & \multicolumn{2}{|c|}{ 女性 } \\
\hline 腹部肥満 & $53.2 \% / 59.2 \%$ & 腹部肥満 & 18.3\%/26.2\% \\
\hline $\begin{array}{l}\text { 高 TG 血症または } \\
\text { 低 HDL 血症 }\end{array}$ & $33.9 \% / 37.8 \%$ & $\begin{array}{l}\text { 高 TG 血症または } \\
\text { 低 HDL 血症 }\end{array}$ & 16.7\%/18.2\% \\
\hline 血圧高値 & $56.2 \% / 68.5 \%$ & 血圧高値 & $45.0 \% / 59.7 \%$ \\
\hline 高 FPG 血症 & $11.1 \% / 19.2 \%$ & 高 FPG 血症 & $4.5 \% / 10.0 \%$ \\
\hline \multicolumn{2}{|c|}{ Metabolic Syndrome = 17.6\%/26.4\% } & \multicolumn{2}{|c|}{ Metabolic Syndrome = 5.5\%/8.8\% } \\
\hline
\end{tabular}

した. 端野・壮瞥町研究 ${ }^{10,11)}$ で, 降圧薬, 抗糖尿 病薬, 抗高脂血症薬を服用していない 40 歳以上 の男性における 4 つの危険因子の頻度をみると， 血圧高值 56\%, 腹部肥満 $53 \%$, 高中性脂肪血症 あるいは低HDLコレステロール血症 $34 \%$, 高血 糖 $11 \%$ であった（表 3 ）。血圧高值のうち 140/ $90 \mathrm{mmHg}$ 以上の高血圧は $46 \%$ であった. 薬剤服 用者も含めると血圧高值 $69 \%$, 腹部肥満 $60 \%$, 脂肪代謝異常 38\%, 血糖高值 19\% であった. 女 性の成績では，新しい基準によるメタボリック
シンドロームの頻度は, 40 歳以上の男女で降圧 薬，抗糖尿病薬，抗高脂血症薬を服用していな い比較的健常と思われる対象では各々 $18 \%, 6 \%$ であった ${ }^{22}$. 一方, 薬郕服用者を血圧や血糖高值 として診断基準 $(+$ ） とみなすとメタボリック シンドロームの頻度は男女で $26 \% ， 9 \%$ と国民 健康・栄養調査の成績と同じであった.メタボ リックシンドロームと判定された男性対象にお いて, 4 つの危険因子をどの程度有するかをみる と, 当然腹部肥満は $100 \%$ となり, 脂質代謝異 


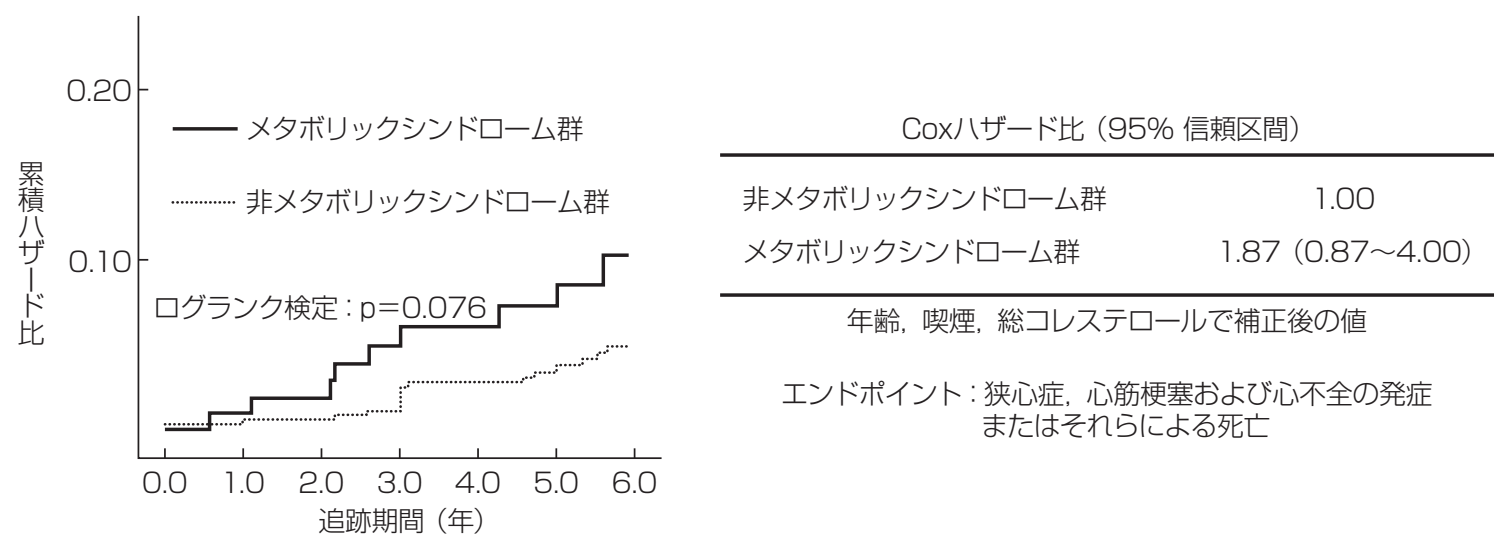

図 . 端野・壮瞥町の男性における日本基準のメタボリックシンドロームの心イベントに対するリスク

表 4. Cox's Proportional Hazards Regression（非 MS 群に対する各危険因子の心疾患発症リスク）

\begin{tabular}{|c|c|c|}
\hline & \multicolumn{2}{|c|}{ Hazard ratio (95\% Confidence interval) } \\
\hline 非 MS & 1.0 & \\
\hline $\mathrm{HT}(+)$ & $2.37(1.18 \sim 4.78)$ & $p=0.016$ \\
\hline 腹部肥満（+） & $2.04(0.96 \sim 4.34)$ & $p=0.064$ \\
\hline 高 TG 血症（+） & $2.20(0.82 \sim 5.90)$ & $p=0.117$ \\
\hline 低 HDL 血症 (+) & $2.07(0.88 \sim 4.86)$ & $p=0.095$ \\
\hline 高FPG 血症 (+) & $2.20(0.82 \sim 5.90)$ & $p=0.117$ \\
\hline
\end{tabular}

Adjusted for age, smoking and total cholesterol

表 5. メタボリックシンドロームの構成要素と CHD の Hazard Ratios (ARIC study)

\begin{tabular}{lll}
\hline & Women $(n=6.881)$ & Men $(n=5,208)$ \\
\hline 高血圧 & $2.89(2.18 \sim 3.80)$ & $1.55(1.32 \sim 1.83)$ \\
低 HDL-C 血症 & $1.70(1.30 \sim 2.22)$ & $1.59(1.34 \sim 1.88)$ \\
高 TG 血症 & $1.22(0.84 \sim 1.50)$ & $1.00(0.84 \sim 1.19)$ \\
空腹時高血糖 & $0.99(0.69 \sim 1.42)$ & $1.13(0.91 \sim 1.39)$ \\
ウェスト径増大 & $1.05(0.79 \sim 1.39)$ & $0.93(0.78 \sim 1.11)$ \\
\hline
\end{tabular}

Data are means $\pm S D$

*Adjusted for age, race/ARIC center, LDL cholesterol, and smoking. (A.M. McNeill, Diabetes Care 28 : 385-390, 2005)

常は $89 \%$, 血圧高值は $88 \%$ であり, 血糖高值は 36\%であった ${ }^{13)}$ 。このようにメタボリックシン ドロームにおいて, 高血圧は頻度の面から重要 な構成因子であることが明らかにされている.
2）メタボリックシンドロームにおける心血管 疾患発症

本邦の診断基準によるメタボリックシンドロー ムの予後をみると, 我々の端野・壮瞥町研究で は, メタボリックシンドロームを有するものは, 無いものに比して, 心疾患 1.9 倍 (図), 糖尿病 
新規発症 2.2 倍, CKD 2.5 倍多いことが判明して いる.

一方メタボリックシンドロームでは高血圧発 症率は高值を示し, Cox比例ハザードモデルにお いては, 年齢, 性別, 糖尿病の有無, 総コレス テロール值, 契煙, 飲酒, 推定糸球体濾過值で 補正後のハザード比は 1.61 (95\%CI：1.16〜2.25) であった. Kaplan-Meier法による累積発症曲線 に関して男女別に検討したところ，男女共メタ ボリックシンドローム群で有意に高血圧発症率 は高值を示した。

高血圧を含むメタボリックシンドローム構成 因子 4 つのうち, どの要因が心血管疾患発症に 大きな影響を与えるかを検討した我々の端野・ 壮瞥町研究の成績を表 4 に示す。高血圧を必須 としたメタボリックシンドロームの場合の心血 管疾患発症率は 2.34 倍で唯一有意な要因であっ た. 同様の検討は米国のARIC研究においてもさ れている．表 5 に示すように，男女共に高血圧 とHDLコレステロールが心筋梗塞発症の有意な 要因となっていた. メタボリックシンドローム 構成因子の中で, 高血圧は頻度的にも予後的に も極めて重要な因子であることが示されている.

\section{おわりに}

危険因子が集積した状態にあるメタボリック シンドロームでは, 心血管系疾患発症も有意に 高く,これらの危険因子の程度は軽い場合でも, 集積した状態に対する留意が必要となる。一方, メタボリックシンドロームの診断基準を構成す る要因の中で高血圧は頻度も高く, 心血管疾患 発症リスクとしても重要な要因であり, メタボ 対策における血圧対策の重要性が示唆される。 そして，血圧なら 130〜139/85〜89 mmHgの疾 患まではいっていないものでも他の危険因子, 特に腹部肥満がある場合には心血管疾患の一次 予防上生活習慣改善を中心にした介入が必要で
ある。

$$
\text { 文献 }
$$

1) World Health Organization: Definition. Diagnosis and classification of diabetes. Mellitus and its complications. Part 1 : Diagnosis and classification of diabetes. Mellitus, world health organization, Geneva, 1999.

2) Expert panel on detection, evaluation, and treatment of high blood cholesterol in adults : Executive summary of the third report of the National cholesterol education program (NCEP) expert panel on detection, evaluation, and treatment of high blood cholesterol in adults (Adult treatment panel III). JAMA $285: 2486,2001$.

3) International Diabetes Federation.Worldwide definition of the metabolic syndrome. Available at: http://www.i df.org $/$ node $/ 1271$ ? node $=1429$.

4）メタボリックシンドローム診断基準検討委員会：メタボ リックシンドロームの定義と診断基準. 日内会誌 94 : 188-203, 2005.

5) Alberti KG, et al: Harmonizing the metabolic syndrome: a joint interim statement of the International Diabetes Federation Task Force on Epidemiology and Prevention; National Heart, Lung, and Blood Institute; American Heart Association;World Heart Federation;International Atherosclerosis Society; and international association for the Study of Obesity. Circulation 120 : 1640-1645, 2009.

6) Grundy SM, et al : Diabetes and management of Metabolic Syndrome An American Health Association/National Heart, Lung, and Blood Institute Statement. Circulation $12: 2005$.

7) Miyawaki T, et al: Metabolic syndrome in Japanese diagnosed with visceral fat measurement by computed tomography. Proc Japan Acad 81 (Ser B) : 471-479, 2005.

8) Hara K, et al: A proposal for the cutoff point of waist circumference for the diagnosis of metabolic syndrome in the Japanese population. Diabetes Care 29:1123-1124, 2006.

9) Eguchi M, et al : Visceral Obesity in Japanese Patients with Metabolic Syndrome:Reappraisal of Diagnostic Criteria by CT Scan. Hypertens Res 30 : 315-323, 2007.

10）竹内 宏, 他：日本人男性におけるMetabolic Syndrome とインスリン抵抗性の検討一端野 - 壮瞥町研究一. 糖尿 病 $46: 739-744,2003$.

11）竹内 宏, 他 : NCEP-ATP III. Metabolic Syndromeとイ ンスリン抵抗性の関連. 男女別検討一端野・壮瞥町研究一, 第7回心血管内分泌代謝学会 Program. Abstracts. 2003, 104.

12）島本和明：特集：糖尿病とメタボリックシンドローム. メタボリックシンドロームの疫学. プラクティス 23 (2) : 151-156, 2006.

13）大西浩文, 他：地域男性住民における日本の診断基準に よるメタボリックシンドロームと心イベントとの関連. 医学のあゆみ 219:807-808, 2006. 